\title{
Cloning, sequencing and analysis of expression of a Butyrivibrio fibrisolvens gene encoding a $\beta$-glucosidase
}

\author{
Long-Liu Lin, Elaine Rumbak, Harold Zappe, Jennifer A. Thomson* and David R. Woods \\ Department of Microbiology, University of Cape Town, PB Rondebosch 7700, South Africa
}

(Received 29 January 1990; revised 28 March 1990; accepted 12 April 1990)

\begin{abstract}
The cloning, expression and nucleotide sequence of a $3.74 \mathrm{~kb}$ DNA segment on pLS215 containing a $\beta$-glucosidase gene (bglA) from Butyrivibrio fibrisolvens $\mathrm{H17c}$ was investigated. The $B$. fibrisolvens bglA open reading frame (ORF) of 2490 bp encoded a $\beta$-glucosidase of 830 amino acid residues with a calculated $M_{\mathrm{r}}$ of 91800 . In Escherichia coli C600(pLS215) cells the $\beta$-glucosidase was localized in the cytoplasm and these cells produced an additional protein with an apparent $M_{\mathrm{r}}$ of approximately 94000 . The $b g l A$ gene was expressed from its own regulatory region in $E$. coli and a single mRNA initiation point was identified upstream of the bglA ORF and adjacent to a promoter consensus sequence. The primary structure of the $\beta$-glucosidase showed $>\mathbf{4 0} \%$ similarity with a domain of 237 amino acids present in the $\beta$-glucosidases of Kluyveromyces fragilis and Clostridium thermocellum. The $B$. fibrisolvens $\beta$-glucosidase-hydrolysed cellobiose to a limited extent, cellotriose to cellobiose and glucose, and cellotetraose and cellopentaose to predominantly glucose.
\end{abstract}

\section{Introduction}

The importance of Butyrivibrio fibrisolvens in the digestion of cellulose and hemicellulose in the rumen has been reported by Shane et al. (1969), Margherita \& Hungate (1963), Orpin et al. (1985) and Hespell et al. (1987). These reports have shown that $B$. fibrisolvens is the predominant bacterium in the rumen of animals surviving under adverse conditions, e.g. the high-arctic Svalbard reindeer and the semi-starved Zebu cattle in Kenya. They therefore suggest that this species may be more resilient than other rumen bacteria. Recombinant DNA technology was used to investigate the cellulolytic enzymes of $B$. fibrisolvens.

The hydrolysis of cellulose to glucose requires at least three groups of enzymes: endoglucanases (EC 3.2.1.4), cellobiohydrolases (EC 3 2.1.91) and $\beta$-glucosidases or cellobiases (EC 3 2.1 .21) (Coughlan, 1985). Berger et al. (1989) reported the cloning, nucleotide sequence and characterization of an endoglucanase (endl) gene from the cellulolytic $B$. fibrisolvens strain $\mathrm{H} 17 \mathrm{c}$ that showed regions of similarity with the Clostridium thermocellum celE endoglucanase. Analysis of $\beta$-glucosidase activity is

Abbreviations: MUC, 4-methylumbelliferyl $\beta$-D-cellobioside; MUG, 4-methylumbelliferyl $\beta$-D-glucoside; ORF, open reading frame.

The nucleotide sequence data reported in this paper have been submitted to GenBank and have been assigned the accession number M31120. essential as these enzymes can be rate-limiting in cellulose hydrolysis (Coughlan, 1985). We have constructed a gene bank of $B$. fibrisolvens H17c DNA in $E$. coli and report the molecular analysis of a $\beta$-glucosidase ( $b g l A)$ gene and the activity of the encoded enzyme.

\section{Methods}

Bacterial strains, plasmids and growth conditions. The bacterial strains and plasmids used in this study are listed in Table 1 . The cloning vector pEB1 is an E. coli/Bacillus subtilis shuttle vector with positive selection for inserted DNA fragments in E. coli. pEB1 was constructed by replacing the pBR322 fragment of pLP1202 (Robson \& Chambliss, 1986; Ostroff \& Péne, 1983) with pEcoR252, which is a derivative of pEcoR251 lacking the PstI site in the $\beta$-lactamase gene (P. Janssen, personal communication). The structure of pEcoR251 (a gift from $M$. Zabeau, Plant Genetic Systems, Gent, Belgium) is similar to other plasmids utilizing inactivation of the EcoRI endonuclease gene as a selective marker (e.g. Cheng \& Modrich, 1983) and has been described previously (Zappe et al., 1986). B. fibrisolvens $\mathrm{H} 17 \mathrm{c}$ was grown in M10 medium (Caldwell \& Bryant, 1966). The growth conditions were described previously by Strydom et al. (1986). E. coli strains were grown in Luria-Bertani (LB) medium (Maniatis et al., 1982) and ampicillin $\left(100 \mu \mathrm{g} \mathrm{ml}^{-1}\right)$ was used in selecting for transformants.

Preparation of DNA. Chromosomal DNA from B. fibrisolvens was obtained by the method of Berger et al. (1989). Plasmid DNA was prepared by an alkaline lysis procedure (Ish-Horowicz \& Burke, 1981). The DNA was purified by $\mathrm{CsCl}$-ethidium bromide density gradient centrifugation, n-butanol extraction and 2-propanol precipitation (Maniatis et al., 1982). 
Table 1. Bacterial strains and vectors

\begin{tabular}{|c|c|c|}
\hline & Relevant characteristics & Reference \\
\hline \multicolumn{3}{|l|}{ Strain } \\
\hline $\begin{array}{l}\text { B. fibrisolvens } \mathrm{H} 17 \mathrm{c} \\
\text { E. coli } \mathrm{C} 600\end{array}$ & $\begin{array}{l}\text { Wild-type } \\
\mathrm{F}^{-} \text {thi-1 thr-1 leuB6 lacYI }\end{array}$ & \\
\hline E. coli $\mathrm{C} 600$ & $\begin{array}{l}\mathrm{F}^{-} \text {thi-1 thr-1 leuB6 lacY } 1 \\
\text { tonA21 supE44 } \lambda^{-}\end{array}$ & Wood (1966) \\
\hline E. coli $\mathrm{K} 514$ & $\begin{array}{l}r_{\mathrm{k}}-m_{\mathrm{k}}{ }^{+} \text {derivative of } E \\
\text { coli } \mathrm{C} 600\end{array}$ & \\
\hline E. coli LK 111 & $\begin{array}{l}\text { lacI lacZ } \Delta \mathrm{M} 15 \text { derivative } \\
\text { of } E \text {. coli } \mathrm{K} 514\end{array}$ & Zabeau \& Stanley (1982) \\
\hline E. coli JM103 & $\begin{array}{l}\Delta(\text { lac-pro }) \text { thi strA supE } \\
\text { endA sbcB hsdR }-\mathrm{F}^{\prime} \text { traD36 } \\
\text { proAB lacl } I^{\top} \mathrm{Z} \Delta \mathrm{M} 15\end{array}$ & $\begin{array}{l}\text { Messing et al. } \\
(1981)\end{array}$ \\
\hline \multicolumn{3}{|l|}{ Vector } \\
\hline pEB1 & $\mathrm{Cm}^{\mathrm{r}} A \mathrm{p}^{\mathrm{r}}$ & This paper \\
\hline $\begin{array}{l}\text { pLS215 } \\
\text { Bluescript }^{R}\end{array}$ & $\begin{array}{l}\mathrm{Cm}^{r} \mathrm{Ap}^{\mathrm{r}} \\
\mathrm{Ap}^{\mathrm{r}}\end{array}$ & Stratagene \\
\hline & & \\
\hline
\end{tabular}

Construction and screening of a B. fibrisolvens $\mathrm{H17c}$ genomic library. B. fibrisolvens chromosomal DNA was partially digested by Sau3A endonuclease and fractionated on a sucrose density gradient (Maniatis et al., 1982). The DNA fragments ranging from 4-10 kb in length were pooled and ligated with pEB1 which had been digested with $B g I I I$ endonuclease. The ligated DNA was used to transform competent $E$. coli LK 111 cells (Dagert \& Ehrlich, 1979). Transformants were selected on LB agar containing ampicillin $\left(100 \mu \mathrm{g} \mathrm{ml}^{-1}\right)$. Colonies were lifted off the plates on Whatman no. 1 filter paper discs and saturated with $1 \mathrm{ml}$ 4-methylumbelliferyl $\beta$-D-cellobioside (MUC; Sigma) at a concentration of $0.02 \%(\mathrm{w} / \mathrm{v})$ in $0.1 \mathrm{M}$-sodium acetate buffer, $\mathrm{pH} 5.0$. The discs were incubated for $10 \mathrm{~min}$ at $37^{\circ} \mathrm{C}$ and examined for fluorescent halos under UV light ( $254 \mathrm{~nm})$. Plasmids were analysed by standard procedures (Maniatis et al., 1982).

Southern blot analysis. B. fibrisolvens chromosomal DNA and pLS 215 were digested to completion with $E c o \mathrm{RV}$, fractionated by electrophoresis in $0.8 \%(\mathrm{w} / \mathrm{v})$ agarose gels in $40 \mathrm{~mm}$-Tris/acetate, $2 \mathrm{~mm}$-EDTA (pH 8.0) buffer, and transferred to Hybond N (Amersham) (Smith \& Summers, 1980). pLS215, nick-translated with $\left[\alpha^{-32}\right.$ P]dCTP (Rigby $e t$ $a l ., 1977)$ was used as a hybridization probe.

Nucleotide sequencing. DNA fragments were subcloned in Bluescript vectors (Stratagene) and exonuclease III was used to generate two sets of overlapping deletions of opposite polarity (Henikoff, 1984). Sequencing was done by the chain termination method of Sanger et al. (1977) using a Sequenase kit (United States Biochemical Corp.). The nucleotide and deduced amino acid sequences were analysed using an IBM XT computer and DNA tools or Genepro (version 3.1) programs.

Primer extension. mRNA from E. coli $\mathrm{C} 600(\mathrm{pLS} 215)$ was extracted by the method of Aiba et al. (1981). A synthetic 17-oligomer (5'GCTGTAACCCTTTCACC-3') complementary to nucleotide positions 235 to 251 (Fig. 2) was labelled at the $5^{\prime}$-end with $\left[\gamma^{-32} \mathrm{P}\right] \mathrm{ATP}$ [2000 Ci mmol-1 $\left.\left(74 \mathrm{TBq} \mathrm{mmol}^{-1}\right)\right]$ using $\mathrm{T} 4$ polynucleotide kinase. The labelled primer ( $1 \mathrm{pmol}$ ) was hybridized to $5 \mu \mathrm{g}$ of mRNA isolated from E. coli $\mathrm{C} 600$ (pLS215) in TE buffer (10 mM Tris/HCl, pH 8.3, 0.35 mM-EDTA). After ethanol precipitation, the samples were incubated in $25 \mu \mathrm{l} 50 \mathrm{~mm}$-Tris/ $\mathrm{HCl}, \mathrm{pH} 8.3,8 \mathrm{~mm}-\mathrm{MgCl}_{2}, 2 \mathrm{~mm}$-DTT, $1 \mathrm{mM}-\mathrm{dNTPs}$ and $34 \mathrm{U}$ of reverse transcriptase at $42^{\circ} \mathrm{C}$ for $60 \mathrm{~min}$. A DNA sequencing reaction was carried out using the same oligonucleotide as a primer and electrophoresed alongside the RNA-primerextended products on a $6 \%$ polyacrylamide $/ 7 \mathrm{M}$-urea sequencing gel.

In vitro transcription and translation. A prokaryotic-DNA-directed in vitro transcription and translation kit (no. N380; Amersham) was used as specified by the manufacturers. The resulting proteins were separated by SDS-PAGE (Laemmli, 1970). Pharmacia low-molecularmass standards were used as markers.

Cell fractionation. Periplasmic extracts were prepared from early stationary phase $E$. coli C600(pLS215) cultures $(200 \mathrm{ml})$ by the osmotic shock procedure of Willis et al. (1974). Cytoplasmic fractions were prepared from osmotically shocked cells by sonication on ice $(10 \mathrm{~s}$ bursts for a total of $100 \mathrm{~s}$ ). The preparation was clarified by centrifugation for $15 \mathrm{~min}$ at $27000 \mathrm{~g}$ at $4{ }^{\circ} \mathrm{C}$ and samples were stored at $-20^{\circ} \mathrm{C}$.

Enzyme assays. $\beta$-Glucosidase activity was assayed by the method of Deshpande et al. (1984) with the following modifications. The assay mixture contained $0.25 \mathrm{ml}$ of diluted cell extract and $0.25 \mathrm{ml}$ of $3.4 \mathrm{~mm}-$ $p$-nitrophenyl $\beta$-D-glucoside in $0.05 \mathrm{M}$-phosphate/citrate buffer (pH 5.0). The reaction mixtures were incubated at $42^{\circ} \mathrm{C}$ for $30 \mathrm{~min}$, and the reaction was stopped by the addition of $0.5 \mathrm{ml} 14 \%(\mathrm{w} / \mathrm{v})$ $\mathrm{Na}_{2} \mathrm{CO}_{3}$; after dilution with $1 \mathrm{ml} \mathrm{H}_{2} \mathrm{O}$ the absorbance at $400 \mathrm{~nm}$ was measured. One unit of enzyme activity was defined as the amount of enzyme releasing $1 \mu \mathrm{mol} p$-nitrophenol $\mathrm{min}^{-1}$.

Activities of $\beta$-galactosidase and $\beta$-lactamase in cell extracts were assayed by the methods of Pardee et al. (1959) and Sykes \& Nordstrom (1972), respectively.

Hydrolysis of cellobiose, cellotriose, cellotetraose and cellopentaose (obtained from AECI) was determined by incubating the cell extracts $(20 \mu \mathrm{l})$ with $100 \mu \mathrm{l}$ of the dextrin $\left(10 \mathrm{mg} \mathrm{m}^{-1}\right.$ in phosphate/citrate buffer) at $42{ }^{\circ} \mathrm{C}$. Samples were taken at various times and analysed in an HPLC system equipped with a model 156 refractive index detector (Beckman). Separation was achieved on a C18 column (Waters). The column was held at room temperature and filtered water was used as an

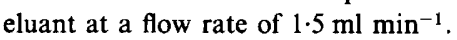

Protein concentrations were determined by the dye-binding method of Bradford (1976) using BSA as a standard.

\section{Results and Discussion}

\section{Cloning and expression of a $\beta$-glucosidase gene from B. fibrisolvens in E. coli}

A MUC-positive E. coli LK111 transformant was isolated on LB agar plates containing ampicillin. The $E$. coli cells contained a recombinant plasmid which was 


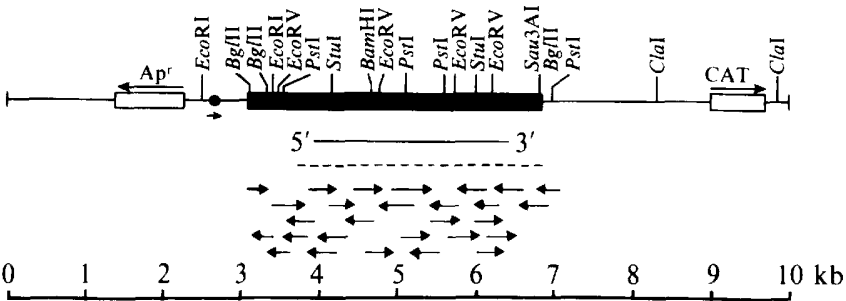

Fig. 1. Restriction map and sequencing strategy of plasmid pLS215. Single and bold lines and open boxes represent vector DNA, $B$. fibrisolvens insert DNA and antibiotic resistance genes, respectively. The circle and arrow beneath denote the position and direction of the $\lambda$ rightward promoter. The extent of the $b g l A$ transcript is indicated by the solid line below the restriction map. The broken line indicates the extent of the nucleotide sequence shown in Fig. 2. The arrows denote the direction and extent of sequence determination.

designated pLS215. E. coli C600(pLS215) cells also showed activity towards 4-methylumbelliferyl $\beta$-D-glucoside (MUG) but no carboxymethylcellulase activity. pLS215 contained a $3.7 \mathrm{~kb}$ DNA insert which was characterized by restriction analysis (Fig. 1). Deletion of the $\lambda$ rightward promoter on the $0.9 \mathrm{~kb} E c o$ RI fragment did not affect expression of the $\beta$-glucosidase gene $(b g l A)$ in $E$. coli, and it was concluded that the $b g l A$ gene was expressed from a regulatory region present in the insert.

The origin of the cloned fragment on pLS215 was determined by Southern blotting with ${ }^{32}$ P-labelled pLS215 as a probe against $B$. fibrisolvens chromosomal DNA digested with EcoRV endonuclease. The insert DNA on pLS215 contained four EcoRV restriction sites (Fig. 1) and the plasmid hybridized to five bands of EcoRV-digested chromosomal DNA. The three which represented the internal fragments of pLS215 had the predicted sizes of $0 \cdot 6,1 \cdot 1$ and $1 \cdot 4 \mathrm{~kb}$ (results not shown).

\section{Nucleotide sequencing}

The nucleotide sequence of the $3.74 \mathrm{~kb}$ DNA fragment contained an open reading frame (ORF) encoding 830 amino acids with a calculated $M_{\mathrm{r}}$ of 91800 (Fig. 2).

The $\mathrm{G}+\mathrm{C}$ content of the nucleotides within the ORF was $46.1 \mathrm{~mol} \%$ which corresponds well with the average $\mathrm{G}+\mathrm{C}$ content of the B. fibrisolvens genome of $42 \mathrm{~mol} \%$ (Mannarelli, 1988).

The region upstream of the ORF, between nucleotides 55 and 84 , contained a promoter sequence which consisted of a TTCAAA -35 region and TTTTAT -10 region separated by $17 \mathrm{bp}$ (Fig. 2). This promoter sequence resembled the consensus sequence of the $\sigma^{70}$ RNA polymerase recognition site of $E$. coli (Hawley \& McClure, 1983; Cowing et al., 1985). Primer extension experiments indicated that this was a functional promoter sequence in $E$. coli and a transcriptional initiation point was detected 7 bp downstream of the -10 region (Fig. 3). No other transcriptional initiation point could be detected in the region upstream of the $b g l A$ gene.

A possible ribosome-binding site (AACGAGG) was situated $8 \mathrm{bp}$ upstream of the putative ATG initiation codon. The stop codon of the $b g l A$ gene is followed by an inverted repeat sequence and a region encoding a stretch of $5 \mathrm{U}$ residues (Fig. 2). The potential stem/loop structure that could be formed in the resultant mRNA message had a $\Delta G=-1.21 \mathrm{kcal} \mathrm{mol}^{-1}$ $\left(-5.06 \mathrm{~kJ} \mathrm{~mol}^{-1}\right)$ (calculated according to Salser, 1977) and consisted mainly of A and U residues. It is therefore unlikely that the structure would function as a $\rho$-independent terminator in $E$. coli.

Table 2. Distribution of $\beta$-glucosidase in E. coli C600(pLS215) cells

Values are means of three experiments; standard errors of means were less than $10 \%$ of the reported values.

\begin{tabular}{lccc}
\hline \hline \multirow{2}{*}{ Fraction } & \multicolumn{3}{c}{ Total activity (units) } \\
\cline { 2 - 4 } & $\beta$-Glucosidase & $\beta$-Galactosidase & $\beta$-Lactamase \\
\hline Supernatant & 1 & 79 & 110 \\
& $(4)$ & $(<1)$ & $(30)$ \\
Periplasmic & $<1$ & 47 & 231 \\
& $(<1)$ & $(<1)$ & $(63)$ \\
Cytoplasmic & 25 & 34000 & 26 \\
& $(96)$ & $(99)$ & $(7)$ \\
\hline \hline
\end{tabular}

* Activity units: $\beta$-glucosidase, $\mu \mathrm{mol} p$-nitrophenol released $\min ^{-1}$; $\beta$-galactosidase, nmol $o$-nitrophenol released $\min ^{-1} ; \beta$-lactamase, $\mu \mathrm{mol}$ ampicillin hydrolysed $\mathrm{min}^{-1}$. Numbers in parentheses represent the percentage of total activity for the respective enzyme. 
AACAAACAGAATTGTTGGAAACTTTTTTATATGCAATATTACTTTAACACAGAATGTCTG

GTGATGGTATATGTTTTTTCTTCCTGAGTTATATATTTCAAATCTTAGATGTGCTATGCT 120 TTTATGGCAGA -10 RBS ATGGAGAAATGGGCAAGAATCAAATATACACCAAATCTTCCGCTTGGAGAGAATGGTGAA 240 $\begin{array}{llllllllllllllllllll}M & E & K & W & A & R & I & K & Y & T & P & N & \text { L } & \text { P } & \text { L } & \text { G } & \text { E } & \text { N } & G & E\end{array}$ AGGGTTACAGCGAGTCAGAAGCACATTGAGCTTTCATGCGAGGCAGCATGTGAGGGAATG 300 $\begin{array}{llllllllllllllllllll}R & V & T & A & S & Q & K & H & I & E & L & S & C & E & A & A & C & E & G & M\end{array}$ GTACTTCTCAAGAATGACAGAAACGTTCTTCCTATCAGAAAGGGCACAAGAGTAGCCCTC 360 $\begin{array}{llllllllllllllllllll}\mathrm{V} & \mathrm{L} & \mathrm{L} & \mathrm{K} & \mathrm{N} & \mathrm{D} & \mathrm{R} & \mathbf{N} & \mathrm{V} & \mathrm{L} & \mathbf{P} & \mathrm{I} & \mathrm{R} & \mathrm{K} & \mathbf{G} & \mathbf{T} & \mathbf{R} & \mathbf{V} & \mathbf{A} & \mathrm{L}\end{array}$ TTTGGAAAGGGAGTATTTGACTATGTAAAAGGCGGCGGTGGTAGCGGAGATGTAACAGTT 420 $\begin{array}{lllllllllllllllllllll} & F & G & K & G & V & F & D & Y & V & K & G & G & G & G & S & G & D & V & T & V\end{array}$ CCTTACATCAGAAACCTCTACGAAGGCCTTTCTCAGTACACATCAGACATTTCAATTTAC 480 $\begin{array}{llllllllllllllllllll}P & Y & I & R & N & L & Y & E & G & \text { L } & S & Q & Y & T & S & D & I & S & I & Y\end{array}$ GACAAATCTGTCAGATTCTATCAGGAATATGTAGCAGACCAGTACAGACTTGGAATTGCA 540 $\begin{array}{llllllllllllllllllll}D & K & S & V & R & F & Y & Q & E & Y & V & A & D & Q & Y & R & I & G & I & A\end{array}$ CCAGGCATGATCAAAGAGCCGGCTCTTCCGGAAGATATTCTTGCAGATGCAGCAGCCTAT 600 $\begin{array}{llllllllllllllllllll}\mathbf{P} & G & \text { M } & \text { I } & \text { K } & \text { E } & \text { P } & \text { A } & \text { L } & \text { P } & \text { E } & \text { D } & \text { I } & \text { L } & \text { A } & \text { D } & \text { A } & \text { A } & \text { A } & \text { Y }\end{array}$ GCAGATACTGCAATCATCGCAATCAGCAGATTCTCCGGAGAAGGCTGGGACAGAAAGGTT 660 $\begin{array}{llllllllllllllllllll}A & D & T & A & I & I & A & I & S & R & F & S & G & E & G & W & D & R & K & V\end{array}$ GCAGGCGTTGACAGAGAAATCAAGTGCGAAGCCAAGGACCTCGTAGAGCAGGGCAACAAG 720 $\begin{array}{llllllllllllllllllll}A & G & V & D & R & E & I & K & C & E & A & K & D & L & V & E & Q & G & N & K\end{array}$ ATATTTGATCATGGTGATTTCTACCTCACAAATGCTGAGAAGAAGATGGTCAAGATGGTA 780 $\begin{array}{llllllllllllllllllll}I & F & D & H & G & D & F & Y & \text { L } & \text { T } & \text { N } & \text { A } & \text { E } & \text { K } & \text { K } & \text { M } & \text { V } & \text { K } & \text { M } & \text { V }\end{array}$

AAAGAGAACTTCTCAAGCGTCATTGTAGTCATGAATGTCGGAGGAGTCGTAGACACAACA 840 $\begin{array}{lllllllllllllllllllllll}K & E & N & F & S & S & V & I & V & V & M & N & V & G & G & V & V & D & T & T\end{array}$ TGGTTTAAAAAGGATGACCAGATTTCATCAGTCCTCATGGCATGGCAGGGTGGAATTGAA 900 $\begin{array}{llllllllllllllllllll}W & F & K & K & D & D & Q & I & S & S & V & L & M & A & W & Q & G & G & I & E\end{array}$ GGCGGACTTGCCGCAGCCAGGATCCTTCTTGGCAAGGTTAATCCTTCAGGTAAGCTCTCA 960 $\begin{array}{llllllllllllllllllll}G & G & L & A & A & A & R & I & \text { L } & \text { L } & G & K & \text { V } & \text { N } & \text { P } & \text { S } & \text { G } & K & \text { L } & S\end{array}$

GATACATTCGCAGCAAGGCTTGAAGACTATCCTTCAACAGAGGGCTTCCACGAAGATGAT 1020 $\begin{array}{llllllllllllllllllll}D & \text { T } & F & A & A & R & \text { L } & \text { E } & \text { D } & \text { Y } & \text { P } & \text { S } & \text { T } & \text { E } & \text { G } & \text { F } & \text { H } & \text { E } & \text { D } & \text { D }\end{array}$

GACTACGTGGATTACACAGAAGATATCTACGTTGGCTATAGATATTTCGAGACCATTCCC 1080 $\begin{array}{lllllllllllllllllllll}D & Y & V & D & Y & T & E & D & I & Y & V & G & Y & R & Y & F & E & T & I & P\end{array}$

GGGGCAAAAGAGAAAGTTAACTACCCCTTTGGCTATGGCCTTTCCTATACAACTTTCCTG 1140 $\begin{array}{llllllllllllllllllll}G & A & K & E & K & V & N & Y & \text { P } & \text { F } & \text { G } & \text { Y } & \text { G } & \text { L } & \text { S } & \text { Y } & \text { T } & \text { T } & \text { F } & \text { L }\end{array}$ CTTGAAGACTATAAGGCAGAGCCTTTTGTGGCTTCAGCAGCAGACGAGGTCGGTAAATCT 1200 $\begin{array}{llllllllllllllllllll}I & E & D & Y & \mathbb{K} & A & E & P & F & V & A & S & A & A & D & E & V & G & K & S\end{array}$ 
GATAGCGACCTTGCAGATGCAATCGTAGCCTCAGTTACAGTCACAAACATTGGCAAGATT $\begin{array}{llllllllllllllllllllllllll}D & S & D & L & A & D & A & I & V & A & S & V & T & V & T & N & I & G & K\end{array}$ CCGGGCAAAGAGGTTGTTCAGCTCTACTACAGCGCTCCTCAGGGCAAGCTCGGTAAGCCT $\begin{array}{llllllllllllllllllllllll}P & G & K & E & V & V & Q & L & Y & Y & S & A & P & Q & G & K & L & G & K & P\end{array}$ GCTAAAGTCCTTGGCGGCTATGCCAAGACAAGGCTACTGCAGCCGGGAGAGAGCCAGAGA $\begin{array}{llllllllllllllllllll}A & K & V & L & G & G & Y & A & K & T & R & L & L & Q & P & G & E & S & Q & R\end{array}$ GTGACAATTGCTCTTTATATGGAGGATATGGCATCTTACGACGACCTTGGCAAGGTTAAA $\begin{array}{llllllllllllllllllllll}V & T & I & A & L & Y & M & E & D & M & A & S & Y & D & D & L & G & K & V & K\end{array}$ AAGGCTGCCTGGCTCCTTGAAAAAGGTGAATATCATTTCTTCCTTGGAACATCAGTAAGA

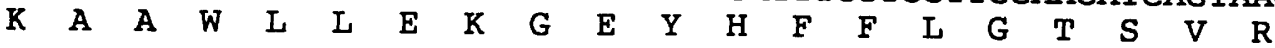
GACACAAGGCTTCTTGATTACACCTATGAACTTTCTAAGAACATAATAGTTGAACAGGTC $\begin{array}{llllllllllllllllllll}D & T & R & L & L & D & Y & T & Y & E & L & S & K & N & I & I & V & E & Q & V\end{array}$ TCAAACAAGCTCGTTCCAACATCTCTTCCCAAGAGAATGCTTGCTGATGGCACATATGAG $\begin{array}{llllllllllllllllllll}S & N & K & L & V & P & T & S & L & P & K & R & M & L & A & D & G & T & Y & E\end{array}$

GAACTTCCTCAGACAGAACCTGTAGATACTTATGCAACAATCTTCCCAAGACCTAAGAAC

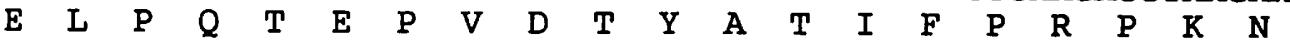
TGGAAAGAAACAATTGAGCACGACGTATTAAAGACTCCTGTAGTTCGTCCACAGGACAGA 1740 $\begin{array}{lllllllllllllllllllll}\mathbf{W} & \mathrm{K} & \mathbf{E} & \mathrm{T} & \mathrm{I} & \mathrm{E} & \mathrm{H} & \mathrm{D} & \mathrm{V} & \mathrm{L} & \mathrm{K} & \mathrm{T} & \mathrm{P} & \mathrm{V} & \mathrm{V} & \mathrm{R} & \mathrm{P} & \mathbf{Q} & \mathrm{D} & \mathbf{R}\end{array}$ TTCCAGCTCTTTTTGCCACCTAAGGAAGGTGACCCTAAGAAATTTATCGAAGTTGCAGAA 1800 $\begin{array}{llllllllllllllllllll}\mathbf{F} & \mathbf{Q} & \mathrm{L} & \mathrm{F} & \mathrm{L} & \mathrm{P} & \mathrm{P} & \mathrm{K} & \mathrm{E} & \mathrm{G} & \mathrm{D} & \mathrm{P} & \mathrm{K} & \mathrm{K} & \mathrm{F} & \mathrm{I} & \mathrm{E} & \mathrm{V} & \mathrm{A} & \mathrm{E}\end{array}$ TGCAAGGTGACACTTGAAGACTTTATTGCACAGCTATCTAACGAGCAGCTTGCAAGCCTT 1860 $\begin{array}{llllllllllllllllllll}C & K & V & T & K & E & D & F & I & A & Q & L & S & N & E & Q & L & A & S & L\end{array}$ CTTGGAGGACAGCCAAATGTCGGAATGGCTAACACCTTTGGATACGGCAACCTTCCTGAG $\begin{array}{llllllllllllllllllll}I & G & G & Q & P & N & V & G & M & A & N & T & F & G & Y & G & N & \text { L } & P & E\end{array}$ GTTGGAGTTCCTAATGCCCAGACCTGTGATGGTCCTGCAGGTGTCCGTATTGCACCGGAA 1980 $\begin{array}{llllllllllllllllllll}V & G & V & P & N & A & Q & T & C & D & G & P & A & G & V & R & I & A & P & E\end{array}$ GTTGGTGTTGTGACTACAGCATTCCCATGTTCAACCCTTCTTGCATGCACATGGAATGAA 2040 $\begin{array}{llllllllllllllllllll}\mathrm{V} & \mathrm{G} & \mathrm{V} & \mathrm{V} & \mathrm{T} & \mathrm{T} & \mathrm{A} & \mathbf{F} & \mathbf{P} & \mathrm{C} & \mathbf{S} & \mathrm{T} & \mathrm{L} & \mathrm{L} & \mathrm{A} & \mathrm{C} & \mathbf{T} & \mathrm{W} & \mathbf{N} & \mathrm{E}\end{array}$ GATATCTGCTACGAAGTCGGAGTTGCAGGCGGAGAAGAGGCCAAGGAGTGCAATTTTGGT 2100 $\begin{array}{llllllllllllllllllll}D & I & C & Y & E & V & G & V & A & G & G & E & E & A & K & E & C & N & F & G\end{array}$ GCATGGCTTACTCCTGCTGTTAACATCCATAGAAGCCCTCTTTGCGGCAGAAACTTTGAG 2160 $\begin{array}{llllllllllllllllllll}A & W & \text { L } & \text { T } & \text { P } & A & \text { V } & \text { N } & \text { I } & \text { H } & \text { R } & \text { S } & \text { P } & \text { L } & \text { C } & \text { G } & \text { R } & \text { N } & \text { F } & \text { E }\end{array}$ TACTACTCCGAAGATCCATTCCTTGCAGGTAAACAGGCAGCAGCTATGGTTCGTGGTATC $\begin{array}{llllllllllllllllllll}\mathrm{Y} & \mathrm{Y} & \mathrm{S} & \mathrm{E} & \mathrm{D} & \mathrm{P} & \mathrm{F} & \mathrm{L} & \mathrm{A} & \mathbf{G} & \mathrm{K} & \mathbf{Q} & \mathrm{A} & \mathrm{A} & \mathrm{A} & \mathbf{M} & \mathrm{V} & \mathrm{R} & \mathbf{G} & \mathrm{I}\end{array}$ 2220 CAGAGCAACAACATAATTGCTACACCTAAACATTTTGCCCTCAACAACAAGGAATCCAAT 2280 $\begin{array}{llllllllllllllllllll}\mathbf{Q} & \mathbf{S} & \mathbf{N} & \mathbf{N} & \mathrm{I} & \mathbf{I} & \mathbf{A} & \mathbf{T} & \mathbf{P} & \mathbf{K} & \mathbf{H} & \mathbf{F} & \mathbf{A} & \mathbf{L} & \mathbf{N} & \mathbf{N} & \mathbf{K} & \mathbf{E} & \mathbf{S} & \mathbf{N}\end{array}$ 
TTTGAAATCATTGTTAAAGAGCAGAGCCCTGGAGCATCATGTCTTCAATACAATATAGTT

D

Fig. 2. Nucleotide sequence of the $B$. fibrisolvens bglA structural gene and flanking regions. Open circles indicate transcriptional start points for the $b g l A$ gene and the associated arrow indicates the direction of transcription. Consensus -10 and -35 regions of the $b g l A$ promoter are underlined and the ribosome-binding sequence (RBS) is boxed. Inverted repeat sequences are shown by converging arrows. The signal peptide of the downstream ORF is underlined. 


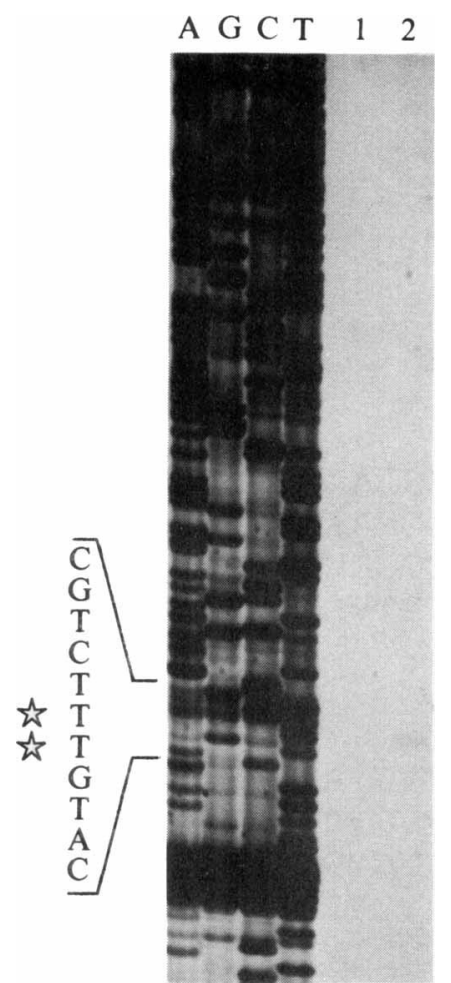

Fig. 3. Primer extension analysis of the 5 -end of bglA mRNA. An oligonucleotide complementary to nucleotide positions 235-251 (Fig. 2) was hybridized to RNA from E. coli C600 (pLS215) cells (lane 2) and a control without RNA (lane 1). A sequencing reaction was done using the oligonucleotide as a primer with DNA from pLS215. The stars mark two possible transcription initiation sites.

\section{Amino acid sequence, localization and in vitro transcription-translation}

The deduced amino acid sequence of the $B$. fibrisolvens $\beta$-glucosidase was compared with the sequences of the $\beta$-glucosidases from the fungi Kluyveromyces fragilis (Raynal et al., 1987) and Candida pelliculosa (Kohchi \& Toh-e, 1985), and the bacterium Clostridium thermocellum (Gräbnitz et al., 1989), and showed 13, 13 and 12\% similarity respectively. In contrast to the thermophilic bacterial $\beta$-glucosidase from Clostridium thermocellum, which showed extensive homology with the fungal $\beta$ glucosidases (Gräbnitz et al., 1989), the $B$. fibrisolvens $\beta$-glucosidase is not related to the fungal enzymes. The peptide sequence implicated in the catalytic activity of the fungal (Bause \& Legler, 1980) and Clostridium thermocellum (Gräbnitz et al., 1989) $\beta$-glucosidases was not present in the $B$. fibrisolvens $\beta$-glucosidase. Although there was low overall similarity between the $B$. fibrisolvens $\beta$-glucosidase and the fungal-type $\beta$-glucosidases, a sequence of significant similarity between the $B$. fibrisolvens enzyme (residues 207-444), and the $\beta$ glucosidases of $K$. fragilis (residues 618-830, 42\% similarity) and Clostridium thermocellum (residues 448$661,41 \%$ similarity) was detected (Fig. 4). This region of homology was absent in the Candida pelliculosa $\beta$ glucosidase (Gräbnitz et al., 1989).

The homology between the amino acid sequence of the $B$. fibrisolvens $\beta$-glucosidase and the bacterial $\beta$-glucosidases from E. coli (Schnetz et al., 1987), Caldocellum saccharolyticum (Love et al., 1988) and an Agrobacterium spp. (Wakarchuk et al., 1988) was determined. The $B$. fibrisolvens enzyme showed $<15 \%$ similarity with these bacterial $\beta$-glucosidases which also show insignificant similarity when compared with one another.

Experiments on the localization of the $B$. fibrisolvens $\beta$ glucosidase in $E$. coli cells showed that $95.8 \%$ of the enzyme activity was present in cytoplasmic fractions and only low levels of activity were detected in periplasmic fractions and the culture supernatant (Table 2). $\beta$ Galactosidase, a cytoplasmic enzyme and $\beta$-lactamase, a periplasmic enzyme, were used as controls to confirm the correct fractionation of the cell compartments.

SDS-PAGE analysis of in vitro translation products of pLS215 showed the presence of, amongst others, a protein with an apparent $M_{\mathrm{r}}$ of approximately 94000 (Fig. 5a, lane 2). The apparent $M_{\mathrm{r}}$ of this protein is in agreement with a predicted $M_{\mathrm{r}}$ of 91800 encoded by the $b g l A$ gene. The proteins with lower apparent $M_{\mathrm{r}}$ values are likely to include proteins and breakdown products encoded by both the $b g l A$ gene and the second ORF shown in Fig. 2. The vector pEB1 did not encode any proteins with apparent $M_{\mathrm{r}}$ values $>30000$ (Fig. $5 a$, lane $1)$.

The cytoplasmic fraction of E. coli C600(pLS215) cells (Fig. $5 b$, lane 4) also contained a protein with an apparent $M_{\mathrm{r}}$ of 94000 . This protein was absent in the corresponding periplasmic fraction and in the periplasmic and cytoplasmic fractions of $E$. coli $\mathrm{C} 600(\mathrm{pEB} 1)$ cells (Fig. $5 b$, lanes 2,1 and 3 respectively). The distribution of this protein between the periplasmic and cytoplasmic fractions of E. coli C600(pLS215) (compare Fig. 5b, lanes 2 and 4) reflects the distribution of $\beta$-glucosidase activity in the respective cell fractions shown in Table 2.

\section{Enzyme activity}

The $B$. fibrisolvens $\beta$-glucosidase cloned in $E$. coli had a $\mathrm{pH}$ optimum of 5.0 and activity decreased rapidly at $\mathrm{pH}$ values above and below $\mathrm{pH} 5 \cdot 0$. The optimum temperature for activity of the $\beta$-glucosidase was $42^{\circ} \mathrm{C}$.

The activity of the cloned $\beta$-glucosidase against various cellodextrins was examined by HPLC (Fig. 6). The $\beta$-glucosidase was able to hydrolyse cellobiose to a limited extent. The enzyme hydrolysed cellotriose to cellobiose and glucose. Cellotetraose and cellopentaose were hydrolysed predominantly to glucose. 

TIVIVTGQQIDLEPF IDNENVTAVIYSSYLGQDFGTVLAKVLFGDENPSG

KLSDTFAARLEDY-PSTEGFHEDDDYVDYTEDIYVGYRYFETIPGAKEKV KLSLSWPFKLQDN-PSFLNFKTEFGRVVYGEDIFVGYRYYEKLQR---KV KLAETF PVKLSHN-PSYLNF PGEDDRVEYKEGLFVGYRYYDTKGI - - EP KLPFTIAKDVNDYIPVIEKVDVPDPVDKFTES IYVDYRYFDKY - $\mathrm{HK}-\mathrm{PV}$

NYPFGYGLSYTTFLLEDYKAEPFVASAADEVGKSDSDLADAIVASVTVTN AFPFGYGLSYTTFEL-DIS--DFK------VK--D-DKIDISV-DVKNTLFPFGHGLSYTKFEYSDISV-DKK----D-V---K-SI INVSV---KNVRYEFGYGLSYSNFSLSDIEIQTLQFFSENAEPAANYSETYQYKOSNMDPS GDKFAGSEVVQVYFSALNSKVKRPVKELKGFEKVH-LEPGEKKTVNIELE -GKMAGKEIVQLYVKDVKSSVRHPEKELKGFEKVF-LNPGEEKTVTFTLD EYTVPEGFKELANYTVPY IHDASS IKANSSYDYPEGY -STEQLDGPKSLA

$\begin{array}{ll}\text { Bf } & 401 \\ \mathrm{Kf} & 795 \\ \mathrm{Ct} & 623 \\ \mathrm{Cd} & 748\end{array}$

MEDMASYDDLGKVKKAAWLLEKGEYHFFLGTSVRDTRL LKDAISYFNEELGK---WHVEAGEYLVSVGTS-SDDIL -KRAFAYYNTQI-KD--WHVESGEYLILIGRS-SRDIV AGGLGGNHTCGMLVTLSLL--KSQIKVLMLVGLHLNCM

Fig. 4. Homologous regions of the $\beta$-glucosidases of $B$. fibrisolvens $(\mathrm{B} f)$, Kluyveromyces fragilis $(\mathrm{K} \mathrm{f})$, Clostridium thermocellum $(\mathrm{Ct})$ and Candida pelliculosa (Cp). Homology was maximized by introducing gaps denoted by a dash (-). Numbers on the left refer to the first amino acid in each line. 
(a)

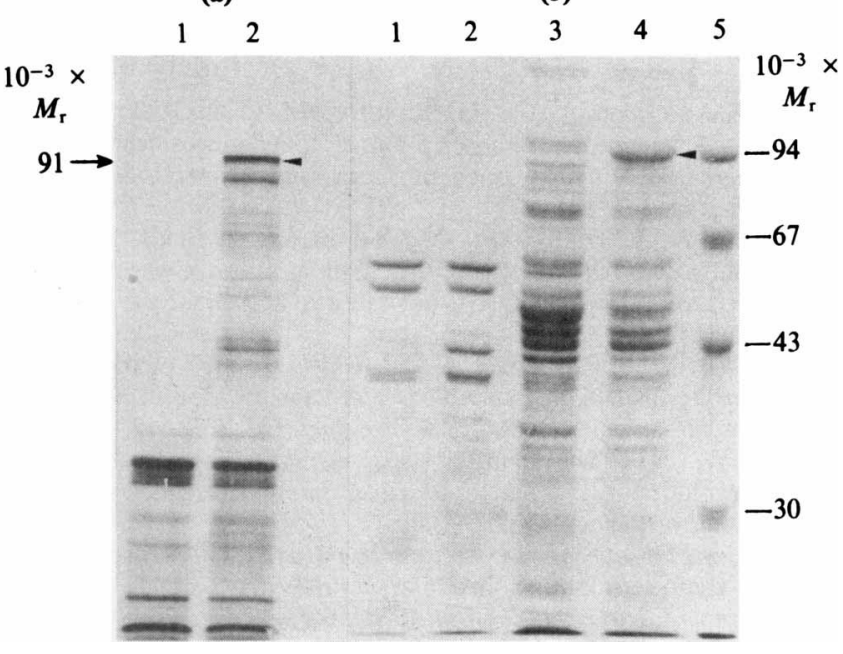

Fig. 5. SDS-PAGE analysis of proteins encoded by pLS215 and pEB1 in vitro $(a)$ and in vivo $(b)$. (a) Lane $1, \mathrm{pEB} 1$; lane 2, pLS215. (b) Lanes 1 and 2, periplasmic fractions of E. coli K 514(pEB1) and K 514(pLS215), respectively; lanes 3 and 4, cytoplasmic fractions of E. coli $\mathrm{K} 514(\mathrm{pEB} 1)$ and K514(pLS215), respectively; lane 5, $M_{\mathrm{r}}$ standards: 94000 , rabbit muscle phosphorylase $\mathrm{b} ; 67000$, BSA; 43000 , ovalbumin 30000 , bovine carbonic anhydrase. The arrow heads indicate the position of the $b g l A$ gene product.

To our knowledge this is the first report of a $\beta$ glucosidase whose major role in the degradation of cellulose is the cleavage of cellodextrins rather than cellobiose. As $B$. fibrisolvens $\mathrm{H} 17 \mathrm{c}$ is able to grow on glucose (Strydom et al., 1986), its genome is likely to encode an enzyme with greater cellobiase activity than the BglA enzyme. We are continuing to screen our gene library for such an enzyme.

The authors wish to thank Jane Morris (AECI Ltd, South Africa) for supplying the cellodextrins and Linda Foulkes for preparing the figures.

\section{References}

Aiba, H., AdhyA, S. \& De Crombrugghe, B. (1981). Evidence for two functional gal promoters in intact Escherichia coli cells. Journal of Biological Chemistry 256, 11905-11910.

BAuse, E. \& LEGLER, G. (1980). Isolation and structure of a tryptic glycopeptide from the active site of $\beta$-glucosidase A3 from Aspergillus wentii. Biochimica et Biophysica Acta 626, 459-465.

Berger, E., Jones, W. A., Jones, D. T. \& Woods, D. R. (1989). Cloning and sequencing of an endoglucanase (endl) gene from Butyrivibrio fibrisolvens H17C. Molecular and General Genetics 219, 193-198.

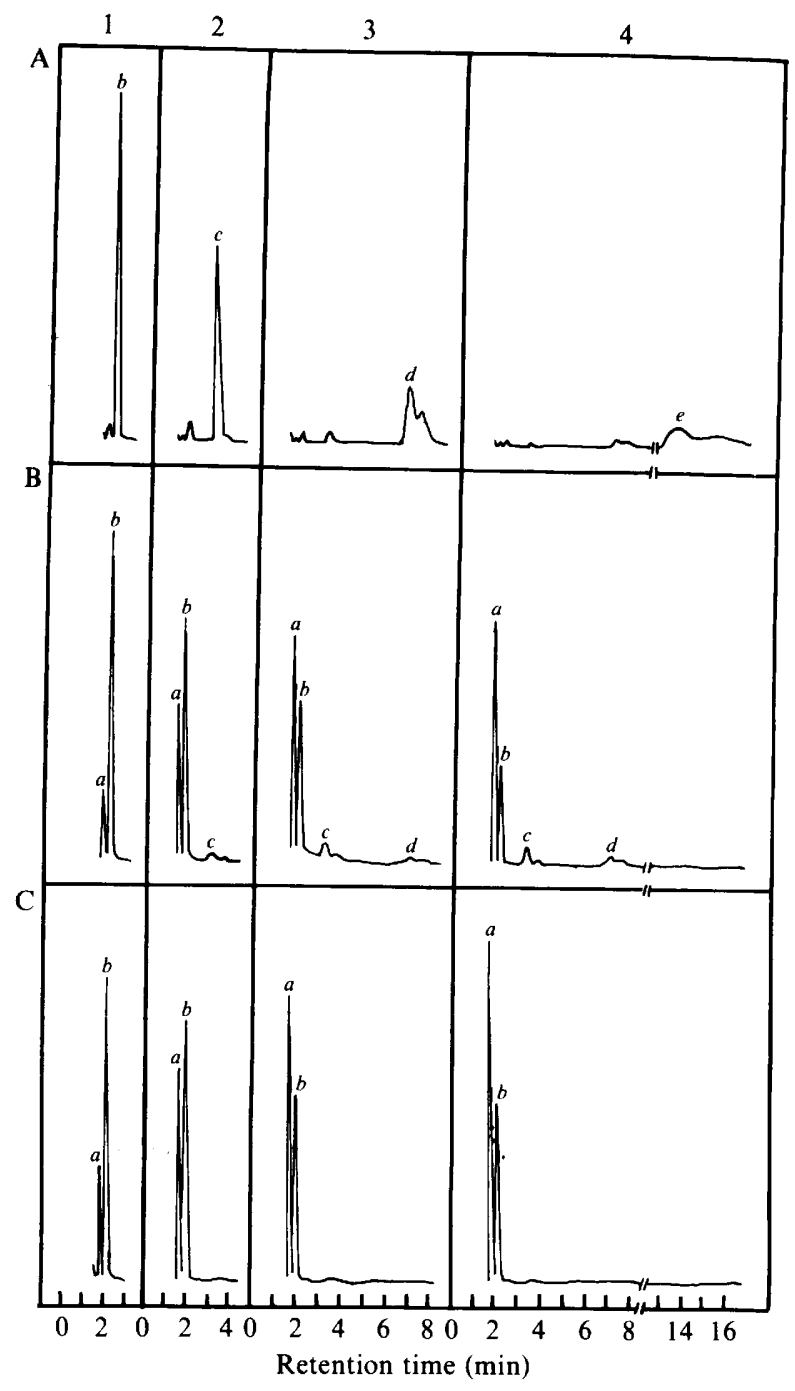

Fig. 6. HPLC analysis of the hydrolysis products of cellulooligosaccharides by the cloned $\beta$-glucosidase. A, standards. B and $\mathrm{C}$, cell extracts incubated at $42{ }^{\circ} \mathrm{C}$ for $60 \mathrm{~min}(\mathrm{~B})$ and $90 \mathrm{~min}(\mathrm{C})$ with $200 \mu \mathrm{g}$ of cellulooligosaccharides in $0.05 \mathrm{M}$-phosphate/citrate buffer $(\mathrm{pH} 5 \cdot 0)$. Substrates used were: panel 1, cellobiose; panel 2, cellotriose; panel 3, cellotetraose; panel 4, cellopentaose. Peaks represent: $a$, glucose; $b$, cellobiose; $c$, cellotriose; $d$, cellotetraose; $e$, cellopentaose.

BRADFORD, M. M. (1976). A rapid and sensitive method for the quantitation of microgram quantities of protein utilizing the principle of protein-dye binding. Analytical Biochemistry 72, 248254.

Caldwell, R. C. \& Bryant, M. P. (1966). Medium without rumen fluid for nonselective enumeration and isolation of rumen bacteria. Applied Microbiology 14, 794-801.

ChENG, S.-C. \& Modrich, P. (1983). Positive selection cloning vehicle useful for overproduction of hybrid proteins. Journal of Bacteriology 154, 1005-1008.

Coughlan, M. P. (1985). The properties of fungal and bacterial cellulases with comment on their production and application. Biotechnology and Genetic Engineering Review 3, 39-109. 
Cowing, D. W., Bardwell, J. C. A., Craig, E. A., Woolford, C., HeNDRIX, R. W. \& Gross, C. A. (1985). Consensus sequence for Escherichia coli heat shock gene promoters. Proceedings of the National Academy of Sciences of the United States of America 82 , 2679-2683.

DAGERT, M. \& EHRLICH, S. D. (1979). Prolonged incubation in calcium chloride improves the competence of Escherichia coli cells. Gene 6, 23-28.

DehORITY, B. A. (1966). Characterization of several bovine rumen bacteria isolated with a xylan medium. Journal of Bacteriology 91 , 1724-1729.

Deshpande, M. V., Eriksson, R.-E. \& Pettersson, L. G. (1984). An assay for selective determination of exo-1,4- $\beta$-glucanases in a mixture of cellulolytic enzymes. Analytical Biochemistry 138, 481487.

Gräbnitz, F., Rucknagel, K. P., Seiß, M. \& Staundenbauer, W. L. (1989). Nucleotide sequence of the Clostridium thermocellum bglB gene encoding thermostable $\beta$-glucosidase B: homology to fungal $\beta$ glucosidases. Molecular and General Genetics 217, 70-76.

HAWLEY, D. K. \& MCCluRE, W. R. (1983). Compilation and analysis of Escherichia coli promoter DNA sequences. Nucleic Acids Research 11, 2237-2255.

HeNIKOFF, S. (1984). Unidirectional digestion with exonuclease III creates targeted breakpoints for DNA sequencing. Gene 28, 351-359.

Hespell, R. B., Wolf, R. \& Bothast, R. J. (1987). Fermentation of xylans by Butyrivibrio fibrisolvens and other ruminal bacteria. Applied and Environmental Microbiology 53, 2849-2853.

IsH-HorowICZ, D. \& BURKE, J. F. (1981). Rapid and efficient cosmid cloning. Nucleic Acids Research 9, 2989-2998.

KoHCHI, C. \& TOH-E, A. (1985). Nucleotide sequence of Candida pelliculosa $\beta$-glucosidase gene. Nucleic Acids Research 13, 6273-6282.

LAEMMLI, U. K. (1970). Cleavage of structural proteins during the assembly of the head of bacteriophage T4. Nature, London 227, 680685.

LOVE, D. R., FISHER, R. \& BERGQUiST, P. L. (1988). Sequence structure and expression of a cloned $\beta$-glucosidase gene from an extreme thermophile. Molecular and General Genetics 213, 84-92.

Maniatis, T., Fritsch, E. F. \& SAmbroOK, J. (1982). Molecular Cloning: a Laboratory Manual. Cold Spring Harbor, NY: Cold Spring Harbor Laboratory.

MANNARELLI, B. M. (1988). Deoxyribonucleic acid relatedness among strains of the species Butyrivibrio fibrisolvens. International Journal of Systematic Bacteriology 38, 340-347.

Margherita, S. S. \& Hungate, R. E. (1963). Serological analysis of Butyrivibrio from the bovine rumen. Journal of Bacteriology 86, 855860 .

Messing, J., Crea, R. \& Seeburg, P. H. (1981). A system for shotgun DNA sequencing. Nucleic Acids Research 9, 309-321.

OrPin, C. G., Mathiesen, S. D., GreenwoOd, Y. \& BliX, A. S. (1985). Seasonal changes in the ruminal microflora of the high-arctic Svalbard reindeer (Rangifer tarandus plytyrhynchus). Applied and Environmental Microbiology 50, 144-151.

OstrofF, G. R. \& PÉNE, J. J. (1983). Molecular cloning with bifunctional plasmid vectors in Bacillus subtilis: isolation of a spontaneous mutant of Bacillus subtilis with enhanced transformability for Escherichia coli-propagated chimeric plasmid DNA. Journal of Bacteriology 156, 934-936.
Pardee, A. B., JACOB, F. \& Monod, J. (1959). The genetic control and cytoplasmic expression of "inducibility" in the synthesis of $\beta$ galactosidase by Escherichia coli. Journal of Molecular Biology 1, 165178.

Raynal, A., Gerbaud, C., Francingues, M. C. \& Guerineau, M. (1987). Sequence and transcription of the $\beta$-glucosidase gene of Kluyveromyces fragilis cloned in Saccharomyces cerevisiae. Current Genetics 12, 175-184.

Rigby, P. W. J., Dieckmann, M., Rhodes, C. \& Berg, P. (1977) Labelling deoxyribonucleic acid to high specific activity in vitro by nick translation with DNA polymerase I. Journal of Molecular Biology 113, 237-251.

Robson, L. M. \& Chambliss, G. H. (1986). Cloning of the Bacillus subtilis DLG $\beta$-1,4-glucanase gene and its expression in Escherichia coli and B. subtilis. Journal of Bacteriology 165, 612-619.

SALSER, W. (1977). Globin mRNA sequences: analysis of base pairing and evolutionary implications. Cold Spring Harbor Symposia on Quantitative Biology 42, 985-1002.

SANGer, F., Nicklen, S. \& Coulson, A. R. (1977). DNA sequencing with chain-terminating inhibitors. Proceedings of the National Academy of Sciences of the United States of America 74, 5463-5467.

SchNeTZ, K., ToloczyKI, C. \& RaK, B. (1987). $\beta$-Glucoside (bgl) operon of Escherichia coli K-12: nucleotide sequence, genetic organization, and possible evolutionary relationship to regulatory components of two Bacillus subtilis genes. Journal of Bacteriology 169 , 2579-2590.

Shane, B. S., Gouws, L. \& Kistner, A. (1969). Cellulolytic bacteria occurring in the rumen of sheep conditioned to low-protein teff hay. Journal of General Microbiology 55, 445-457.

SMITH, G. E. \& Summers, M. D. (1980). The bidirectional transfer of DNA and RNA to nitrocellulose or diazobenzyloxymethyl-paper. Analytical Biochemistry 109, 123-129.

STRYDOM, E., MaCKIE, R. I. \& Woods, D. R. (1986). Detection and characterization of extracellular proteases in Butyrivibrio fibrisolvens H17C. Applied Microbiology and Biotechnology 24, 214-217.

SYKES, R. B. \& NoRDSTROM, K. (1972). Microiodometric determination of $\beta$-lactamase activity. Antimicrobial Agents and Chemotherapy 1, 94-99.

WakarchuK, W. W., Greenberg, N. M., Kilburn, D. G., Miller, R. C. \& WARREN, R. A. J. (1988). Structure and transcription analysis of the gene encoding a cellobiase from Agrobacterium sp. strain ATCC 21400. Journal of Bacteriology 170, 301-307.

Willis, R. C., Morris, R. G., Cirakoglu, C., Schellenberg, G. D., Gerber, N. H. \& Furlong, C. E. (1974). Preparation of the periplasmic binding proteins from Salmonella typhimurium and Escherichia coli. Archives of Biochemistry and Biophysics 162, 64-75.

WooD, W. B. (1966). Host specificity of DNA produced by Escherichia coli : bacterial mutations affecting the restriction and modification of DNA. Journal of Molecular Biology 16, 118-133.

ZABEAU, M. \& StANLEY, K. K. (1982). Enhanced expression of cro- $\beta$ galactosidase fusion proteins under the control of $P_{R}$ promoter of bacteriophage $\lambda$. EMBO Journal 1, 1217-1224.

ZAPPE, H., JONES, D. T. \& WoODS, D. R. (1986). Cloning and expression of Clostridium acetobutylicum endoglucanase, cellobiase and amino acid biosynthesis genes in Escherichia coli. Journal of General Microbiology 132, 1367-1372. 